\title{
PORNOGRAFI DALAM PERSPEKTIF SEJARAH
}

\author{
Oleh: Ajat Sudrajat \\ (FISE - UNY)
}

\begin{abstract}
Abstrak
Pornografi telah mengundang kontroversi, sejak dari yang anti sampai pada yang ingin membiarkan dan mempertahankannya. Banyak hal yang terkait dengan pornografi, sejak dari soal sejarah, kebudayaan, politik, teknologi, sampai ekonomi. Demikian pula, pornografi telah melahirkan arus pemikiran yang beragam.

Pornografi diyakini memiliki sejarah panjang seiring dengan perjalanan umat manusia. Tetapi, kapan sesunguhnya pornografi mulai mendapat perhatian, tentu harus ada bukti-bukti historis yang menguatkannya. Tanpa bermaksud mengabaikan sejarah panjang pornogarafi, abad ke-20 telah mencatat terjadinya pengembangbiakan pornografi yang luar biasa. Pengembang-biakan ini tidak lepas dari perkembangan kebudayaan manusia, sejak dari demokratisasi, kebebasan berekspresi, ditemukannya mesin cetak, alat fotografi, dan teknologi komunikasi. Sehingga akhirnya, pornografi menjadi bagian komoditi yang menghasilkan milliaran rupiah.
\end{abstract}

\section{Pendahuluan}

Pornografi berasal dari kata pornē ("prostitute atau pelacuran") dan graphein (tulisan). Dalam Encarta Referency Library (Downs: 2005). dinyatakan bahwa pornografi adalah segala sesuatu yang secara material baik berupa film, surat kabar, tulisan, foto, atau lain-lainnya, menyebabkan timbulnya atau munculnya hasrat-hasrat seksual. Pengertian yang sama dinyatakan pula dalam Encyclopedia Britannica (2004), pornografi adalah penggambaran perilaku erotik dalam bukubuku, gambar-gambar, patung-patung, film, dan sebaginya, yang dapat menimbulkan rangsangan seksual. Dengan demikian, siapa pun yang menyajikan gambar, tulisan, atau tayangan yang mengumbar aurat sehingga menimbulkan nafsu atau hasrat-hasrat seksual, memancing birahi dan erotisme, dengan sendirinya terlibat dalam perbuatan pornografi.

Sementara itu, para pemikir feminis, seperti Gloria Steinem, Catharine MacKinnon, dan Andrea Dworkin, mengemukakan definisi pornografi yang berbeda, dan membedakannya dengan erotika. Mereka mendefinisikan pornografi sebagai ekspresi yang bersifat 
seksual dari kaum wanita, sedangkan erotika adalah ekspresi yang bersifat seksual yang mengambarkan atau memamerkan postur tubuh baik pada laki-laki maupun perempuan.

Kata Erotika berasal dari kata Yunani erōtika. Dalam Encarta Dictionary dikatakan, erotika adalah seni atau literatur yang cenderung membangkitkan hasrat-hasrat seksual dengan cara yang eksplisit. Sedangkan menurut Encyclopedia Britannica, kata erotika secara khusus dipakai untuk menunjuk pada karya-karya yang menempatkan unsur seksual sebagai bagian dari aspek estetik. Erotika biasanya dibedakan dari pornografi, terutama karena yang disebut terakhir difahami memiliki tujuan utama membangkitkan gairah seksual.

Terlepas dari definisi di atas dan adanya perbedaan antara pornografi dan erotika, kedua istilah ini biasanya dipakai untuk menunjuk kepada karya seni atau literatur yang mengeksploitasi tematema seksual. Antara pornografi dan erotika dapat digambarkan sebagai dua sisi dari sekeping mata uang, yang masing-masing di antaranya tidak dapat dipisahkan dari unsur seksual.

\section{Pornografi dalam Lintasan Sejarah}

Kita tidak tahu secara tepat mengenai asal usul dan bentuk yang paling awal dari pornografi. Alasannya barangkali karena tidak layak atau tidak patut untuk mentransmisikan dan melestarikan hal yang tidak pantas. Meskipun demikian, terdapat bukti-bukti sejarah, terutama dalam kebudayaan Barat, yang berkaitan dengan ekspresi pornografik ini.

Salah satu bukti sejarah mengenai ekspresi pornografik dalam kebudayaan Barat dapat ditemukan dalam nyanyian-nyanyian cabul pada masa Yunani Kuno. Nyanyian-nyanyian cabul ini dilakukan dalam perayaan-perayaan yang dipersembahkan untuk menghormati dewa Dionysius. Bukti-bukiti kuat lainnya dapat ditemukan dalam Kebudayaan Romawi di Pompeii, di sana terdapat lukisan-lukisan erotik yang berasal dari abad pertama masehi, yang menghiasai benteng atau tembok tempat berpesta. Bukti lainnya adalah, tulisan yang berasal dari masa klasik, yaitu tulisan seorang penyair Roma yang bernama Ovid, dalam karyanya yang berjudul Ars amatoria (Art of Love), suatu tulisan mengenai seni merayu, seni membangkitkan birahi, dan seni untuik menimbulkan hasrat-hasrat sensual (Encarta: 2005). 
Selama Abad Pertengahan Eropa, pornografi telah meluas meskipun dalam ukuran yang rendah. Ekspresi ponografi ketika itu kebanyakan diungkapkan dalam bentuk lelucon, sanjak yang tidak bermutu, dan syair yang bersifat satiris. Satu karya yang terkenal berjudul the Dacameron, tulisan Giovanni Boccaccio, di dalamnya memuat 100 -an cerita yang bernada cabul.

Penemuan alat cetak telah membangkitkan kembali ambisi karya-karya tulis yang bersifat pornografik. Pada umumnya karyakarya itu berisi unsur-unsur humor dan romantis serta ditulis dengan ramuan yang menghibur. Kebanyakan dari karya-karya ini memiliki kesamaan dengan tulisan-tulisan yang ada pada masa klasik, yaitu mengungkapkan dan menggambarkan suka duka dan tipu daya dalam perkawinan. The Heptameron, karya Margaret of Angoulême, memiliki kesamaan dengan the Dacameron, yang memanfaatkan kelompok pencerita. Beberapa cerita di dalamnya juga adalah mengenai cerita-cerita cabul (Encarta: 2005).

Pada abad ke-18, di Eropa untuk pertama kali muncul karyakarya modern yang sama sekali mengabaikan nilai-nilai dan sepenuhnya ditujukan untuk membangkitkan rangsangan seksual. Bisnis penerbitan dan penjualan karya-karya semacam itu terdapat di Inggris. Buku-buku yang semacam itu antara lain ditulis oleh John Cleland dengan judul Fanny Hill, atau, Memoirs of a Woman of Pleasure (1749). Kira-kira pada masa itu juga, buku-buku yang menggambarkan hal-hal yang bersifat erotik secara luas mulai diproduksi di Paris, yang kemudian dikenal dengan sebutan French Postcards.

Pornografi tumbuh dengan subur pada masa Victoria, sekalipun ketika itu berlaku atau ada larangan terhadap topik-topik yang berbau seksual. Pada tahun 1834, suatu penyelidikan di London menyatakan bahwa toko-toko yang berada di Holywell Street, $57 \%$ persen di antaranya menjual bahan-bahan yang bersifat pornografik. Karya pornografik yang terkenal dari masa Victoria adalah yang berjudul $M y$ Secret Life (1890), dengan penulis anonim. Isi buku itu secara detail menceritakan tentang pencarian seorang laki-laki Inggris akan kepuasan seksualnya (sexual gratification). EB.

Terdapat sejumlah karya literatur erotik sepanjang masa dan di banyak negeri. Di antara contoh yang paling baik untuk literatur erotik selain yang telah disebutkan di atas adalah Kama-sutra, literatur Sanskrit dari abad ke-5. Juga ada syair lirik Persia yang disebut ghazal, kemudian novel Cina dari abad ke-16 yang berjudul Chin p'ing. Karya William Shakespear yang berjudul Venus and Adonis, 
juga masuk dalam arus ini, demikian pula dengan karya D.H. Lawrence yang berjudul Chatterley's Lover.

\section{Pornografi dan Aspek Kehidupan}

Ketika membicarakan persoalan pornografi, banyak hal yang bisa terkait dengannya, seperti sejarah, kebudayaan, biologi, dan teknologi. Dalam perjalanan sejarahnya, pornografi tumbuh dan berkembang seiring dengan semakin berkembangnya kebebasan, yang dalam hal ini tidak bisa dilepaskan dari penyebaran dan persemaian demokrasi.

Meskipun hasrat-hasrat seksual merupakan sesuatu yang bersifat instinktual dan biologikal, tetapi ekspresi seksualitas ini sangat berkaitan dengan faktor-faktor kebudayaan, seperti misalnya bagaimana cara pandang masyarakat mengenai hakkekat hubungan antara laki-laki dan perempuan, ideal-ideal mereka tentang seksualitas, pandangannya mengenai hakekat nilai-nilai moral, dan tingkat kebebasan individu.

Dalam beberapa hal, pornografi juga merupakan ekspresi seksual yang merupakan kecenderungan kuat dari suatu orde sosial tertentu. Sementara itu, bagi orde sosial yang lain, pornografi dipandang sebagai sesuatu yang tabu dan merupakan bentuk pelanggaran hukum. Dalam kedua kasus tersebut, konten dari pornografi merupakan refleksi dan produk dari suatu kebudayaan. Di beberapa negara misalnya, ekspresi bahan-bahan dan pelukisan yang bersifat pornografik dapat ditolerir, tetapi di beberapa negara yang lain ekspresi dan pelukisan semacam itu dilarang sama sekali.

Secara teknologi, perkembangan fotografi dan perfilman memberikan sumbangan yang sangat besar terhadap perkembangbiakan (proliferation) bahan-bahan yang bersifat pornografik. Pornografi yang berkembang pada abad ke-20 belum pernah terjadi sebelumnya, baik dalam hal ragam media yang digunakan atau banyaknya volume karya yang diproduksi. Sejak Perang Dunia II, tulisan-tulisan yang mengenai dan bersifat pornografik secara luas telah digantikan oleh gambaran-gambaran visual yang eksplisit dalam bentuk perilaku erotis, dan dipandang telah lepas dari nilai-nilai sosial.

\section{Pornografi sebagai Komoditi}

Seperti telah dikemukakan di atas, abad 20 mencatat proliferasi pornografi yang luar biasa, dan sejak tahun 1950-an disebut-sebut telah terjadi ledakan dalam industri pornografi. Menurut suatu 
analisis, kecenderungan ini menggambarkan telah terjadinya peningkatan pornografi, disebabkan munculnya teknologi-teknologi baru sebagai sarana distribusi. Di samping budaya patriarkhi, maraknya pornografi adalah karena unsur komersialisme dan industrialisasi atas pornografi ini (Supartiningsih, 2004: 1-12).

Di Amerika, industri pornografi berkembang sejak tahun 1950an yang ditandai dengan diterbitkannya majalah Playboy. Majalah ini untuk pertama kalinya memuat gambar-gambar wanita cantik (girlie magazine). Sejak tahun 1970-an bermunculan majalah-majalah lain yang isinya menyediakan dan memuat hal-hal yang berbau pornografik secara lebih eksplisit. Sementara itu, film-film yang bersifat pornografik mulai dibuat untuk pertama kali kira-kira pada tahun akhi tahun 1960-an dan awal tahun 1970-an. Sejak pertengahan tahun 1980-an, majalah-majalah pornografi dan rumah-rumah produksi mengalami penurunan disebabkan diperkenalkannya teknologi baru, terutama dengan berkembangnya video cassette recorder (VCRs) dan televisi kabel. Sejak tahun 1990-an, dengan berkembangnya jaringan internet, ketersediaan pornografi semakin meningkat, baik di Amerika maupun negara-negara lainnya (DownsEncarta: 2005).

Dewasa ini, pornografi di Amerika merupakan lahan bisnis dengan aset milliaran dollar. Pada tahun 1996, Amerika menghabiskan dana sekitar delapan miiliar dollar berkenaan dengan bahan-bahan yang berbau pornografik, seperti video, program kabel untuk orang dewasa, komputer pornografi, majalah-majalah seks, dan pertunjukanpertunjukan cabul. Kira-kira ada 25.000-an toko yang menjual videovideo pornogrfi. Pada tahun 1992, Amerika telah menyewakan sebanyak 490 juta keping viodeo porno, suatu peningkatan yang substansial dari 75 juta keping pada tahun 1985. Pada tahun 1997, suatu studi mengenai pornografi lewat internet mengatakan kira-kira ada 34.000 web site. Sejumlah studi yang lain mengatakan adanya keterlibatan organisasi-organisasi kriminal dalam penyebaran pornografi ini (Daynes, 1988: 41).

\section{Reaksi Masyarakat terhadap Pornografi}

Berbagai usaha telah dilakukan untuk mengendalikan penyebaran pornografi yang terdapat baik di televisi, gedung-gedung film, dan internet. Banyak negara, seperti Amerika dan Inggris, memberikan pembatasan-pembatasan terhadap bentuk siarannya. Pemerintah berusaha untuk membatasi pertunjukan-pertunjukan cabul 
dengan memperkuat undang-undang percabulan atau undang-undang anti pornografi.

Perhatian yang serius terhadap hal-hal yang berbau pornografi secara eksplisit mulai kelihatan sejak awal abad ke-20. Kecenderungan ini ditandai oleh adanya sejumlah tindakan keras yang dilakukan pemerintah terhadap pornografi, baik yang dlakukan melalui gerakan politik maupun dalam bentuk rekasi-reaksi atas perubahan sosial ini. Misalnya, munculnya kegelisahan yang melanda masyarakat Amerika, Inggris, dan Kanada antara tahun 1890-an sampai 1920-an atas terjadinya dekadensi moral dan kehancuran orde sosial yang melanda negeri-negeri ini.

Sudah sejak lama, masyarakat memperdebatkan tentang karyakarya yang bersifat pornografik. Kebanyakan dari mereka menyatakan perlu adanya kalau bukan harus ada sensor yang (sangat) ketat berkait dengan karya-karya yang bercorak demikian. Karena bagi mereka, pornografi merupakan bentuk ekspresi yang sangat kontroversial dan meresahkan. Seperti diketahui bahwa konseksuensi sosial dari pornografi sudah menjadi subjek perdebatan yang keras di kalangan masyarakat.

Setidaknya, sudah sejak permulaan abad ke-20, keputusankeputusan pengadilan dan perundang-undangan, berusaha untuk mempersempit ruang gerak beredarnya pornografi dan percabulan. Masing-masing negara memiliki pendekatan dan hukum tersendiri terhadap persoalan ini. Meskipun demikian, sampai saat ini masih kurang adanya koordinasi di tingkat internasional, padahal pornografi telah menyebar bagai virus jahat di mana pun di dunia ini melalui berbagai media cetak maupun elektronik.

Di Amerika Serikat misalnya, The Comstock Law, pada tahun 1873, melarang pengiriman setiap bentuk materi yang berbau cabul melalui pos, termasuk materi-materi yang berkaitan dengan aborsi. Atas nama moral kesopanan (moral decency), The Comstock Law berhasil menjaring dan menuntut ratusan karya yang berbau pornografik. Kongres Amerika, melalui hukum tentang percabulan (obscenity laws) antara tahun 1842 dan 1956, telah mengamandemen the Comstock Law. Kemudian, Kongres melalui serangkaian hukum anti-pornografi dan anti-ketidaksenonohan (antipornography and antiindecency laws) berusaha menghadapi bentuk-bentuk teknologi baru dan untuk melindungi anak-anak dari pornografi dan ketidaksenonohan.

The Protection of Children Against Sexual Exploitation Act of 1977 melarang setiap hal yang mengarah pada perilaku pornografi 
(Daynes, 1988: 51). Pada tahun 1988 Kongres Amerika, melalui legislasinya juga menentang perilaku ketidaksenonohan dan percabulan melalui telpon (dial-a-porn). Pada tanggal 26 Juni 1997, Mahkamah Agung Amerika Serikat mengeluarkan the Communications Decency Act (CDA), suatu hukum federal yang melarang distribusi bahan-bahan cabul atau tak senonoh melalui jaringan komputer, seperti internet. CDA merupakan suatu usaha untuk membatasi atau mengurangi bahan-bahan yang bersifat pornografik melalui jaringan internet.

Seiring dengan semakin meningkatnya peredaran majalah yang berbau pornografik di Kanada pada tahun 1950-an, telah mendorong pemerintahnya untuk memperkuat hukum atau undang-undang yang berhubungan dengan tindak percabulan. Karena Konstitusi Kanada secara formal tidak melindungi kebebasan berekspresi sampai tahun 1982, pengadilan-pengadilan tidak membatasi gerakan-gerakan semacam itu atas nama konstitusi. Hukum tahun 1959 mengaskan bahwa materi atau bahan-bahan itu dikatakan cabul apabila memiliki ciri-ciri yang dominan seperti eksploitasi seks yang tidak senonoh, atau apabila seseorang atau lebih melakukan hal-hal berikut, yaitu kriminal, horor, kebengisan, dan kekerasan sesksual. Definisi ini jauh lebih ekspansif dibanding doktrin percabulan yang terdapat di Amerika, yang tidak memasukkan unsur kriminal, kekerasan, horor, dan kebengisan.

Pada tahun 1980-an, koalisi golongan konsevatif dan feminis, mulai menekan para pembuat undang-undang untuk memperkuat hukum percabulan dengan mencabut perlindungan hukum bagi pelaku kekerasan dan diminta untuk menurunkan aksi pornografi. Laporan tahun 1985 dari komite khusus yang menangani pornografi dan prostitusi, juga disebut Komisi Fraser, telah telah meminta kepada parlemen agar pornografi dan prostitusi dimasukkan ke dalam perbuatan kriminal. Pada pertengahan tahun 1980-an, pengadilanpengadilan di Kanada mulai mengakomodasi pendekatan-pendekatan yang dilakukan oleh kaum feminis.

Pada tahun 1985, Pengadilan Tinggi Kanada mengadopsi suatu pandangan yang mengatakan bahwa pornografi telah menurunkan dan menyebabkan dehumanisasi kaum wanita. Pada tahun 1992, Pengadilan mendefinisikan bahwa sesuatu materi dapat disebut sebagai percabulan apabila di dalamnya memuat unsur kekerasan seksual, menurunkan dan menyebabkan terjadinya dehumanisasi perempuan, dan termasuk juga penggambaran seks anak-anak. Hukum pornografi anak Kanada memiliki kesamaan dengan yang terdapat di 
Amerika, kecuali bahwa Kanada juga melarang pornografi anak. Rupanya, Kanada telah berusaha untuk melindungi warga negaranya dari pornografi dan percabulan lebih baik dibanding Amerika. Hasilnya adalah pornografi di Kanada tidak sesemarak dan seekstentif di Amerika. Meskipun demikian, pembatasan-pembatasan terhadap pornografi di Kanada bukan tidak mendapat tantangan.

Pendekatan legal terhadap pornografi dan percabulan dilakukan pula di banyak negara. Di Inggris misalnya, untuk menentukan sesuatu materi dipandang cabul atau tidak, didasarkan pada kriteria isi dan cara mendistribusikannya. Konstitusi Jerman mengamanatkan kewajiban kepada para pembuat undang-undang untuk melindungi kaum muda dan warga negaranya dari bahaya yang diasosiasikan dengan bentuk-bentuk tertentu seperti kekerasan dan percabulan. Denmark memberlakukan hukum percabulan (obscenity laws) pada tahun 1969. Di luar Amerika Serikat dan Eropa, pemerintahan Komunis Cina memberlakukan kontrol yang sangat tinggi terhadap ekspresi yang berlebihan, dan tidak mengizinkan peredaran bahanbahan yang berbau seksual. Mereka meyakini bahwa hal itu akan merusak (detrimental) pandangan Partai Komunis Cina tentang warga negara yang baik.

\section{UU APP di Indonesia: Suatu Harapan}

Seperti telah disebutkan di atas, pornografi di Indonesia bukanlah merupakan fenomena baru. Pornografi di Indonesia boleh jadi seiring dengan perkembangan pornografi di dunia pada umumnya. Ibarat tanaman rumput, walaupun sering diinjak, dicabuti, bahkan dibabat, pornografi tetap tumbuh dengan subur. Menurut catatan Lembaga Pers dan Pendapat Umum di Jakarta (sekarang sudah tidak ada), pada tahun 1953 tercatat adanya buku-buku dan bacaan cabul berisikan perempuan Barat yang telanjang masuk ke Indonesia dengan bebas. Sejak itu pula pemerintah berusaha keras untuk memerangi percabulan dengan menyeret penanggung jawab penerbitan ke pengadilan (Tjipta Lesmana, 1995).

Pada tahun 1954, sejumlah majalah dan buku telah dikirim oleh Polisi Bagian Kesusilaan kepada Kejaksaan Agung. Judul-judul buku tersebut antara lain: Rahasia Sorga Dunia, Sundal terhormat, Gadis Lobang Kubur, Wanita Sepanjang Zaman, Dacameron I dan II, dan Usia Dewasa. Pada tahun 1955, majalah Tjermin edisi 16 dan 23 telah dituntut oleh Polisi karena memuat tulisan yang berjudul Gara-gara buah dada te.buka dan Panitia Penyewaan Sontoloyo. Tahun 1956, 
Pengadilan Negeri Yogyakarta menghukum denda Pemimpin Redaksi Majalah Bikini, karena memuat cerdek berbau cabul. Pada tahun 1957, Pemimpin Redaksi majalah bulanan Roman juga dijatuhi hukuman denda karena judul cerita Tinah dan Induk Semang, yang ternyata bersifat cabul.

Gerakan pemerintah untuk memerangi pornografi dan percabulan tidak pernah berhenti. Gerakan ini merupakan jawaban atas semakin suburnya peredaran bahan-bahan yang berbau pornografi. Peredaran bahan-bahan yang demikian kelihatan semakin mencolok pada masa orde baru. Pada tanggal 2 Oktober 1967, Departemen Penerangan bersama Pengurus Harian PWI Pusat, PWI Jaya dan SPS, Departemen Dalam Negeri, serta Departeman Luar Negeri, menyelenggarakan rapat gabungan yang membahas masalah pornografi dalam pers di Indonesia. Pada tahun 1970, Kejaksanaan Agung membentuk sebuah tim yang bernama "Tim Penelaahan Porno Kejaksaan Agung" di bawah pimpinan Jaksa Agung Muda Bidang Intel. Meskipun demikian, pornografi di Indonesia tetap saja berkembang dengan subur.

Perang terhadap pornografi terus dikumandangkan oleh pemerintah. Pada tahun 1984, pornografi mencapai puncaknnya dengan beredarnya kalender Happy New Year 1984 Sexindo. Kalender ini merupakan yang pertama di Indonesia yang menampilkan perempuan-perempuan telanjang tanpa sehelai benang pun. Memasuki tahun 1988, pornografi di Indonesia mulai menggila lagi. Film dengan judul Pembalasan Ratu Laut Selatan, sangat mengejutkan masyarakat. MUI mengajukan protes keras atas produksi dan peredaran film tersebut. Sebagian kalangan menilai bahwa film tersebut masuk dalam kategori softcore pornography. Pada waktu yang bersamaan, Badan Sensor Film (BSF) juga menarik peredaran film Akibat terlalu Genit (Tjipta Lesmana, 1995:4).

Menurut catatan Badan Sensor Film, selama semester 1 tahun 1984/85, BSF telah menyensor 60-an judul film. Dari judul sebanyak itu, 44 judul atau 67,3\%, harus mengalami pemotongan lantaran menggambarkan adegan porno. Beberapa judul film yang bernada provokatif antara lain: Cinta di Balik Noda, Tergoda Rayuan, Midah Gadis Buronan, Kawin Kontrak, Pengantain Pantai Biru, dan Gadis Simpanan.

Ledakan film pornografi di Indonesia menggila lagi pada awal tahun 1990-an. Pada tahun 1994 misalnya, karena produksi perfilman demikian kuat mengeksploitasi pornografi, pemerintah kembali lagi mencanangkan perang terhadap segala bentuk pornografi. Tengok saja 
judul-judul film yang dirpoduksi tahun itu: Ranjang yang Ternoda, Ranjang Pemikat, Asmara, Perempuan di Persimpangan Jalan, Gairah Malam, Gairah Cinta, Gairah yang Nakal, Gadis Malam, Gadis Metropolis, Janda Kembang, Selir Sriti, Selir Durga Ratih, Akibat Hamil Muda, Kenikmatan Tabu, Setetes Noda Manis, Cinta Dalam Nafsu, Godaan Perempuan Halus, Skandal Ibis, Misteri Permainan Terlarang, Sorgaku Nerakaku. Judul-judul itu baru sebagian dari sekitar 40-an judul film yang dikategorikan porno (Tjpta Lesmana, 1995: 1).

Sepanjang tahun 1990 sampai 1992, hampir seluruh media cetak memberikan sumbangan terhadap proliferasi pornografi. Majalah Jakarta-Jakarta, merupakan majalah terpanas di Indonesia. Hampir pada setiap edisinya, majalah ini tidak pernah tidak menampilkan sampul dengan gambar yang memancing nfasu birahi. Majalah lain yang tidak kalah getol dalam penyajian gambar-gambar sensual adalah Monitor milik KKG (Kelompok Kompas dan Gramedia). Resep yang dipakai Arswendo Atmowiloto ialah mengeksploitasi unsur-unsur seksual, sehingga kemudian dikenal dengan sebutan jurnalisme lher. Pada tahun 23 Oktober 1990, majalah Monitor dibredel disebabkan memuat angket 50 Tokoh yang dikagumi dengan menempatkan Nabi Muhammad pada urutan ke-11, satu tingkat di bawah posisi Arswendo. Hasil angket ini dinilai menghina dan merendahkan Nabi Muhammad serta melukai umat Islam. Mati satu tumbuh seribu, itulah kenyataan yang mengiringi dibredelnya majalah Monitor. Tabloid Bintang dan Citra, terbit hampir berbarengan pada bulan Mei 1991 dengan tema yang sama (Tjpta Lesmana, 1995:8).

Bahan-bahan yang bersifat pornografi dan pornoaksi, baik lewat VCD maupun penayangan gambar atau tulisan di media massa, terus berkembang biak bagai penyaklit menular. Protes-protes dan kecaman senantiasa muncul dari masyarakat. Namun, protes-protes dan kecaman yang dilontarkan masyarakat itu sepertinya hanya berlaku sesaat. Karena setelah protes itu reda, peredaran bahan-bahan pornografi tersebut kembali marak, bahkan dengan intensitas yang jauh lebih tinggi dibanding sebelumnya.

Belajar dari pengalaman negara lain, sudah sewajarnya kalau Indonesia pun memiliki perangkat hukum yang dapat melindungi warga negaranya, terutama anak-anak dan generasi mudanya dari kebiadaban makhluk pornografi. Negara bertanggung jawab dan memiliki kewajiban untuk melindungi warga negaranya dari wabah pornografi. Kalau selama ini, negara seakan tidak begitu konsisten dengan wabah ini, sudah saatnya negara bertindak tegas dan tidak lagi 
berkompromi. Atas nama menjaga moral dan masa depan bangsa, negeri ini harus memiliki perangkat hukum dalam bentuk UndangUndang Anti-Pornografi.

\section{Mainstrim Pemikiran Pornografi}

Meskipun sebagian besar masyarakat sudah gerah dengan aksi pornografi, tidak ada jeleknya apabila berikut ini ditambahkan beberapa mainstrim pem ikiran yang berkaitan dengan pornografi. Sikap terhadap pornografi secara umum dapat dibedakan ke dalam empat perspektif, yaitu: konservatif, feminis, postmodern, dan liberal (Downs: Encarta). Ketegangan di antara pandangan-pandangan ini semakin meningkat seiring dengan membiaknya bahan-bahan yang bersifat pornografik yang beredar melalui media elektronik.

Pertama, perspektif konservatif. Kalangan konservatif melihat pornografi berdasarkan alasan-alsan tradisional mengenai hukum percabulan (obscenity law), yang memfokuskan pada bagaimana pornografi telah merusak moral dan orde sosial. Mereka ingin mendudukkan keinginan-keinginan yang bersifat seksual dikendalikan dan dicegah secara rasional, adanya komitmen interpersonal, bertanggung jawab, dan berkualitas, yang dijaga dengan dilakukannya perkawinan dan komitmen terhadap keluarga.

Perspektif konservatif melihat pornografi sebagai penyakit sosial, karena telah merangsang keinginan-keinginan seks impersonal dan rekreasional. Dengan demikian, pornografi telah menyebabkan dan merangsang terjadinya hubungan yang bebas (seks-bebas) antara laki-laki dan perempuan dan melecehkan lembaga perkawinan. Dalam ha ini, pornografi juga telah memberikan sumbangan terhadap maraknya kekerasan seksual (perkosaan). Pandangan yang konservatif ini didasarkan pada agama dan teori moral sekuler. Di Amerika Serikat dan banyak negara, sejumlah aktivis keagamaan telah bekerja keras dan berjuang melalui gerakan-gerakan anti-pornografi, terutama sejak tahun 1970-an.

Kedua, perspektif feminis. Alur utama dalam perspektif feminis adalah menolak pandangan-pandangan moral dan religius kaum konservatif. Dalam hal ini, menurut kaum feminis, pornografi bukanlah tentang seks, melainkan tentang kekuasaan. Pornografi menggambarkan dan memperkuat kekuasaan kaum laki-laki dan seksualitas dengan menggambarkan wanita sebagai objek seks, untuk memenuhi selera dan kesenangan kaum laki-laki. 
Seperti telah disebutkan di atas, kaum feminis membedakan pornografi dari erotica, yang didefinisikan sebagai pameran tubuh yang dilakukan baik oleh laki-laki maupun perempuan. Kelompok feminis terbelah ke dalam dua arus pemikiran yang berbeda. Sekelompok kaum feminis mendukung adanya pembatasanpembatasan terhadap pornograf, tetapi sebagian lainnya tidak. Kaum feminis yang menolak adanya sensor atas aktivitas pornografik menyatakan dan berkeyakinan bahwa cara-cara seperti itu akan mengarah pada terjadinya sikap yang represif. Menurut kelompok ini, semua bentuk sensor akan membahayakan ekualitas perempuan.

Ketiga, perspektif posmodern. Kalangan posmodern mengkritik adanya sensor. Mereka menuduh kalangan konservatif dan kaum feminis prosensor telah mengadopsi pandangan tentang seks, ekualitas, dan kontrol pemerintah dengan sangat sederhana. Kalangan posmodern sangat skeptik dengan semua penjelasan fenomena sosial yang komplek. Menurut kalangan posmodern, pornografi memiliki banyak pengertian dan akibat, oleh karena itu mereka tidak bermaksud untuk mereduksi atau memperkuatnya. Sama dengan pandangan kaum feminis antisensor, aliansi antara kaum konservatif dan kaum feminis prosensor akan dapat menimbulkan sikap-sikap yang represif.

Keempat, perspektif liberal. Pandangan kaum liberal terhadap pornografi adalah membiarkan setiap aktivitas seksual yang dilakukan oleh orang dewasa, sepanjang hal itu tidak mencelakakan dan membahayakan orang lain. Dalam pandangan ini, pornografi merupakan ekspresi yang sah (legitimate expression) dari pilihan seorang individu. Seperti halnya kaum posmodern, kaum liberal cenderung menafsirkan pornografi secara relatif. Apabila kaum posmodern masih dapat menerima adanya peran regulasi negara atas pornografi, kaum liberal menolak sama sekali pembatasan negara dalam bentuk apa pun atas pilihan individu. Kaum liberal mengkritik setiap klaim mengenai akibat yang merusak dari pornografi.

\section{Akibat atau Pengaruh Pornografi}

Persoalan tentang bagaimana pornografi mempengaruhi kelakuan dan sikap masyarakat terjadi silang pendapat. Kelompokkelompok yang menentang pornografi menyakini bahwa pornografi telah menyebabkan immoralitas, kekerasan seksual, dan perlakuan yang negatif terhadap kaum perempuan, atau bahkan dehumanisasi kaum perempuan. Sementara itu bagi kelompok yang mempertahankan pornografi, selain melihat pornografi sebagai 
hiburan yang tidak terbatas yang dapat membantu mengurangi ketegangan-ketegangan seksual, juga karena di dalam pornografi tersimpan uang dalam julmah milliaran rupiah. Pornografi merupakan komoditi yang dengan cepat dapat menghasilkan uang banyak.

Pada tahun 1986, Komisi Umum Pengacara Amerika yang menangani pornografi menyimpulkan bahwa pornografi telah melahirkan adanya hubungan kausal dengan tindakan-tindakan antisosial yang berupa kekerasan seksual. Selanjutnya, Komisi ini juga menyimpulkan bahwa menurunnya aksi pornografi akan dapat melahirkan sejumlah hubungan kausal. terhadap kekerasan, agresi seksual, dan sikap negatif, seperti halnya mitos bahwa wanita adalah pemuas nafsu.

Suatu penelitian mengenai pornografi, dengan subjek murid lakilaki, memberikan dukungan terhadap tesis yang pertama, dan tidak untuk yang kedua. Menurunnya pornografi tidak serta merta akan menurunkan kekerasan seksual. Meskipun demikian, penelitian itu secara umum memberikan dukungan terhadap pandangan bahwa pornografi itu berbahaya dan membahayakan. Sejumlah penelitian yang lain mengklaim bahwa lebih dari $10 \%$ pornografi menggambarkan kekerasan seksual.

\section{Penutup}

Pornografi sesungguhnya memiliki sejarah panjang seiring dengan perjalanan umat manusia. Terdapat bukti-bukti historis yang menguatkannya sekalipun tidak berasal dari masa yang paling awal. Berdasarkan sejumlah bukti, abad ke-20 mencatat telah terjadinya ledakan dan pengembang-biakan (proliferasi) pornografi yang luar biasa. Proliferasi pornografi ini ternyata tidak bisa dilepaskan dari perkembangan kebudayaan manusia itu sendiri, sejak dari adanya kebebasan berekspresi, ditemukannya mesin cetak, alat fotografi, dan teknologi komunikasi. Sehingga akhirnya, pornografi menjadi bagian komoditi yang menghasilkan milliaran rupiah.

Perkembangan pornografi yang demikian luar biasa ini telah mengundang respon masyarakat. Telah muncul reaksi yang beraneka ragam dari masyarakat terhadap fenomena ini. Sejumlah negara telah berusaha membatasi beredarnya pornografi dengan menetapkan perundang-undangan anti porbografi. Sementara itu, reaksi dari masyarakat luas tercermin dari adanya arus pemikiran yang menentang peredaran bahan-bahan yang berbau pornografik dengan melakukan sensor yang ketat. Meskipun demikian, ada sebagian 
masyarakat yang menginginkan agar pornografi itu dibiarkan saja, selama tidak terkait dengan unsur-unsur kriminal dan kekerasan seksual misanya.

\section{Daftar Pustaka}

Daynes, Byron W. "Pornography: Freedom of Expression of Societal Degradation", dalam Social Regulatory Policy. Boulder and London: Westview Press, 1988.

Downs, Donald A. "Pornography". Microsoft Encarta Reference Library 2005. Microsoft Corporation. All rights reserved. 19932004.

Lesmana, Tjipta. Pornografi dalam Media Massa.Jakarta: Puspa Swara, 1995.

"Pornography". Encyclopedia Britannica 2005 Ultimate Reference Suite, www.britannica. com. Encyclopedia Britannica Inc. 2004.

Reed, Esther D. "Pornography and The End of Morality?", dalam Studies in Christian Ethics, Volume 7 Number 2, Edinburg: T \& T Clark, 1994.

Supartiningsih, "Melacak Akar Masalah Pornografi dan Pornoaksi serta Implikasinya Terhadap Nilai-Nilai Sosial", dalam Jurnal Filsafat, Jilid 36, Nomor 1, April 2004.

\section{Biodata Penulis}

Ajat Sudrajat adalah dosen mata kuliah Sejarah Pemikiran pada Jurusan Pendidikan Sejarah FISE dan dosen Pendidikan Agama Islam di UPT MKU Universitas Negeri Yogyakarta. 